\title{
Analysis of Factors Affecting Student Interest to Continue Their Education to Vocational School
}

\author{
Ahmad Fathoni ${ }^{1 *}$ Jamaludin $^{2}$, Hariadi ${ }^{3}$, and S Yuliana ${ }^{4}$ \\ ${ }^{1234}$ Universitas Hamzanwadi, Lombok, Indonesia \\ Department of Informatics Education, Faculty of Mathematics and Science, Universitas Hamzanwadi, Pancor, \\ Indonesia. \\ "Corresponding author. Email: ahmad.fathonis2ptk@gmail.com
}

\begin{abstract}
The purpose of this study was to determine the interests and factors that influence it to continue their studies to vocational high school. This type of research uses quantitative methods. The population in this study were all grade IX students, totaling 250 students. Data collection techniques using a questionnaire. Data were analyzed using descriptive statistics. The results showed that most of the IX grade students at SMP Negeri 1 Sikur had an interest in continuing their study at SMK with a percentage of $42 \%$. And the factors that influence it are: (a) the factor of student interest in a particular department that has a percentage value of $78 \%$. (b) the factor of school condition or image of SMK which is considered good by students has a percentage value of $48 \%$ (c) the socioeconomic status factor of parents who have a percentage value of $89 \%$.
\end{abstract}

Keywords: Vocational, Interest, factors that influence it

\section{INTRODUCTION}

The view of students to continue their studies to a higher level discusses about students starting junior high schools (SMP) because based on stability will grow through the process. Further education for junior high school needs to be given for further education. In order to get the right education with the potential and talent possessed by junior high school students. In the selection of secondary schools, it is hoped that junior high school students can really answer what they want, there is no need to hesitate in the future or even drop out of school. Vocational High Schools (SMK) or High Schools (SMA) will be issued. Provision of information about secondary schools is carried out by families or schools to improve the stability of students in choosing to continue their studies to high school or vocational school. Students who choose to enter high school will prioritize academic learning such as Language, Natural Sciences and Social Sciences. While students who choose to enter vocational schools will be more emphasized on the skills and skills needed by students, because vocational schools are more intended for prospective workers after graduation. Talents and skills needed by junior high school students must also follow the majors that will be carried out at vocational schools .

Vocational or vocational education is education that is inherent in the development of human life at all times. So that the aim of vocational high schools is in accordance with the Ministry of Education Regulation
No.23 of 2006 in Indonesia concerning Graduates Competency Standards (SKL) that vocational education aims to increase intelligence, knowledge, personality, noble character, and the skills of students to live independently and to follow further education in accordance with its vocational program. In addition to the majors favored at vocational high schools, the interest of middle school students also arises from the socio-economic consequences of parents. Socioeconomic status tends to influence young people in having work knowledge and understanding It can be interpreted that the education chosen is in accordance with the socio-economic conditions of the parents. In addition, quality SMKs can improve the image of SMKs in the eyes of the public.

A good image of a vocational high school can be an attraction for the public, especially junior high school graduates and its equivalent. To continue their studies at SMK, therefore the SMK graduates have an important role in shaping the image of SMK and also having an important role in attracting the interest of junior high school graduates to continue their studies to SMK. In accordance with the theory that pitched the existence of a harmonious school culture will certainly foster good and positive interactions between the components involved in the school community[3][6]. But often junior high school graduates do not know the reason for continuing their studies to vocational high school, just like students of State Vocational High School 1 Sikur located in Sikur Village, Sikur District, East Lombok 
Regency, West Nusa Tenggara. The village of Sikur, where most students do not know the reason for continuing their studies at SMK Negeri 1 Sikur. Of course this must be considered by all parties so that junior high school graduates are more stable to continue their studies at SMK 1 Sikur. The village of sikur is an area that has a growing agricultural potential. The majority of the population in the village of Sikur work by utilizing existing natural resources that is working as farmers, gardens or laborers and the rest work in the service sector as teachers or government employees. This causes most parents to direct their children to continue their studies to vocational high school, hoping that after graduating they will get a job faster.

\section{METHOD}

Search for research answers with quantitative methods with a survey approach. The number of SMKs in Sikur sub-district is $6 \mathrm{SMK}, 3$ private SMK and 2 State SMK. The population used is SMK 1 Sikur with a total population of 1009 students. The sample used was class $\mathrm{X}$ which is 452 new students. Data collection techniques in this study used observation, documents and questionnaires (questionnaire). Calculations with descriptive analysis[9].

\section{RESULTS AND DISCUSSION}

3.1 Interest in Class $X$ Students of SMK Negeri 1 Sikur Continuing Vocational Study in SMK

Based on the data obtained shows that the variable of student interest in continuing their studies to vocational high school can be seen in Table 1 .

Table 1. Student Interest Continuing Study in SMK

\begin{tabular}{|c|c|c|c|}
\hline Category & The answer & Frequency & Percentage(\%) \\
\hline Strongly agree & $80 \%-100 \%$ & 265 & 62 \\
\hline Agree & $60 \%-9.99 \%$ & 148 & 34 \\
\hline Enough & $40 \%-9.99 \%$ & 16 & 3 \\
\hline Disagree & $20 \%-39.99 \%$ & 5 & 1 \\
\hline Strongly Disagree & $0 \%-19.99 \%$ & 0 & 0 \\
\hline \multicolumn{2}{|l}{} & 425 & 100 \\
\hline
\end{tabular}

Based on Table 1, the interest in continuing their studies to the Vocational High School in the strongly agreed category of 265 students with a percentage of $62 \%$, in the agreed category of 148 students with a percentage of $34 \%$, then in the sufficient category of 16 students with a percentage of $3 \%$ and whereas in the category of disagreeing by 5 students with a percentage of $1 \%$. This shows that the majority of class X students of SMK 1 Sikur have an interest in entering SMK with a percentage of $62 \%$.

\subsection{Student Interest in a Specific Department}

Based on the data obtained shows that the factors of student interest in a particular department in Vocational Schools can be seen in Table 2.

Table 2. Student Interest in a Specific Department

\begin{tabular}{|c|c|c|c|}
\hline Category & The answer & Frequency & Percentage(\%) \\
\hline Strongly agree & $80 \%-100 \%$ & 0 & 0 \\
\hline Agree & $60 \%-9.99 \%$ & 0 & 0 \\
\hline Enough & $40 \%-9.99 \%$ & 0 & 0 \\
\hline Disagree & $20 \%-39.99 \%$ & 291 & 68 \\
\hline Strongly Disagree & $0 \%-19.99 \%$ & 134 & 32 \\
\hline & & 425 & 100 \\
\hline
\end{tabular}

Based on Table 2 and the interest of students in a particular department in the Vocational School in the category of strongly disagreeing with 134 students with a percentage of $32 \%$, and in the category of disagreeing with 291 students with a percentage of $68 \%$. This shows that most students choose the category of disagreeing on the student's interest factor in a particular department at Vocational School with a percentage of $78 \%$.

\subsection{School Conditions or Vocational Image}

Based on the data obtained shows that the variable condition of the school or the image of vocational schools can be seen in Table 3 . 
Table 3. School Condition or Vocational Image

\begin{tabular}{|c|c|c|c|}
\hline Category & The answer & Frequency & Percentage(\%) \\
\hline Strongly agree & $80 \%-100 \%$ & 139 & 33 \\
\hline Agree & $60 \%-9.99 \%$ & 174 & 41 \\
\hline Enough & $40 \%-9.99 \%$ & 92 & 21 \\
\hline Disagree & $20 \%-39.99 \%$ & 15 & 4 \\
\hline Strongly Disagree & $0 \%-19.99 \%$ & 5 & 100 \\
\hline
\end{tabular}

Based on Table 3, the school condition or image of Vocational School in the category of strongly agreeing by 39 students with a percentage of $26 \%$, in the category of agreeing by 74 students with a percentage of $48 \%$, then in the category it is sufficient for 30 students with a percentage of $19 \%$ and in the category of disagreeing of 10 students with a percentage of $6 \%$, while in the category of strongly disagreeing by 1 student with a percentage of $1 \%$. This shows that most students choose the category of agreeing on school condition factors or the image of Vocational Schools which are considered good by students with a percentage of $48 \%$.

\subsection{Parental Socio-Economic Status}

Based on Table 4 that has been analyzed by calculating the total percentage of all respondents, it can be seen that respondents who have less socioeconomic status of parents amounted to 237 students with a percentage of $56 \%$ having an interest in continuing their studies to SMK. Whereas for respondents with socioeconomic status of parents is very less by 117 students with a percentage of $28 \%$, also have an interest in continuing their studies to vocational school. The socioeconomic categories are good and quite simultaneously at 18 and 53 students with a percentage of $4 \%$ and $12 \%$. Based on Table 4 , it can be concluded that the majority of class $X$ students in SMK Negeri 1 Sikur when viewed from the socioeconomic status of parents have socioeconomic status in the category of less with a percentage of $56 \%$.

Table 4. Socio-Economic Status of Parents

\begin{tabular}{|c|c|c|c|}
\hline Category & The answer & Frequency & Percentage(\%) \\
\hline Strongly agree & $80 \%-100 \%$ & 0 & 0 \\
\hline Agree & $60 \%-9.99 \%$ & 18 & 4 \\
\hline Enough & $40 \%-9.99 \%$ & 53 & 56 \\
\hline Disagree & $20 \%-39.99 \%$ & 237 & 28 \\
\hline Strongly Disagree & $0 \%-19.99 \%$ & 117 & 100 \\
\hline
\end{tabular}

\section{CONCLUSION}

Based on the results and discussion of the research that has been stated above, it can be concluded as follows: Most students of class X of SMK Negeri 1 Sikur have an interest in continuing their study interest in SMK, with the category of strongly agreeing the percentage of $62 \%$. And the factors that influence it are: (a) students' interest in a particular department in a vocational school that has a category does not agree with the percentage of $68 \%$, stating students who enter vocational school are not because of the existing majors. (b) the condition of the school or the image of SMK which is considered good by students who have a percentage value of $41 \%$ lies in the agreed category, stating the trigger of interest to enter SMK (c) the socioeconomic status of parents who have a percentage value of $56 \%$ with less categories and stated a very influential factor in continuing interest in vocational high schools.

\section{REFERENCES}

[1] Billett, s. (2011). Vocational education. In vocational education. Https://doi.org/10.1007/978-94-007-1954-5

[2] Burge, t. (2013). Cognition through understanding. Cognition through understanding.

Https://doi.org/10.1093/acprof:oso/97801996720 28.001 .0001

[3] J. T. B. Santoso, "Faktor Faktor Yang Mempengaruhi Siswa Smp N Di Kota 
Semarang Memilih Smk," Din. Pendidik., vol. 9, no. 1, pp. 1-20, 2014.

[4] Lucas, b., spencer, e., \& claxton, g. (2012). How to teach vocational education: a theory of vocational pedagogy. Centre for real-world learning, university of winchester, (dec), 133. Retrieved from http://www.skillsdevelopment.org/pdf/how-toteach-vocational-education.pdf

[5] Motivasi, p., hasil, d. A. N., pada, b., \& sumbawa, d. I. S. (n.d.). Pelajaran pemograman dasar menggunakan modul improving motivation and learning outcomes in basic programming using modules in smkn 2 sumbawa. (1), 365376.

[6] Paulista, U. E., Em, P. D. E. P., \& Biológicas, C. (n.d.). Pre-vocational Education in Germany and China. https://doi.org/10.1007/978-3-531-19440-0

[7] Prof.Dr.Sugiyono, Statistik untuk Penelitian. Bandung: CV ALFABETA, 2017.

[8] P. Sudira, "Pre-vocational Courses on Primary Education," no. 0274, 1990.

[9] P. Sudira, Filosofi dan Teori Pendidkan Vokasi dan Kejuruan. Yogyakarta: UNY Press, 2012. 